\title{
Development of Genital Plates in Nymphs of Triatoma pallidipennis, Stål 1872, (Hemiptera: Reduviidae) and its Application as Sexing Method
}

\author{
Milton Rodríguez-Sánchez, Ricardo Alejandre-Aguilar, Benjamín Nogueda-Torres/ ${ }^{+}$, \\ Alejandro D Camacho*, Eliézer Martín-Frías
}

Laboratorio de Entomología Médica, Depto. de Parasitología *Laboratorio de Entomología, Depto. de Zoología, Escuela Nacional de Ciencias Biológicas, Instituto Politécnico Nacional, Prol. Carpio y Plan de Ayala s/n, Col. Casco de Santo Tomás, C.P. 11340, México D. F., México

Searching for morphometric differences between sexes in immature forms, the development of genital plates in the exuviae of Triatoma pallidipennis Stål 1872 nymphs was studied. Differences were found in the form and size of the 9th genital urosternite, it is larger and wider in males as compared to females. This difference is reported in several South American Triatoma species. From our results it is possible to sex early stages from microscopic observation of genital plates in whole insects.

Key words: Triatoma pallidipennis - sexing methods - genital plates - urosternites

The interest on the studies of development of genital plates in immature forms in triatomines has increased due to its application for sexing and taxonomic value (Perlowagora-Szumlewics \& Nigri da Cruz 1972, Da Rosa et al. 1992, Jurberg et al. 1998). Galliard (1935) was first to report morphological evidence from genital plates as useful for sexing 5th nymphal stage in Triatoma protracta (Uhler 1894), T. dimidiata (Latreille 1811) and Rhodnius prolixus, Stål 1872. Further research conducted by Corrêa (1954), Corrêa et al. (1964), Espínola (1966), Ramírez Pérez (1969), Lent and Jurberg (1969), Salgado et al. (1979), Martín and Dávila (1981), Gonçalvez et al. (1985), Jurberg et al. (1986), and Galindez-Giron et al. (1999), include the use of optic and scanning electronic microscopy (SEM).

Most studies were conducted on South American species such as T. maculata (Erichson 1848), T. pseudomaculata Corrêa and Espínola 1964, T. brasiliensis Neiva 1911, T. infestans (Klug 1834), Psammolestes coreodes Bergroth 1911, and Panstrongylus megistus (Burmeister 1835). Previous works by Galliard (1935), Ryckman (1962) and Martin and Dávila (1981) were done on Mexican Triatoma species, yet further research is required on the subject. The present work was conducted on T. pallidipenis, a species of the "phyllosoma complex", widely distributed in México. Because of its peridomestic behavior in some regions, it is an interesting species for epidemiology (Lent \& Wygodzinsky 1979, Zárate \& Zárate 1985, Beltrán \& Carcavallo 1985, Velasco-Castrejón 1991, Martínez-Ibarra \& Katthain-Duchateau 1999). We studied the development of genital plates through the life cycle

\footnotetext{
${ }^{+}$Corresponding author. Fax: +52-55-5729.6300 ext. 62399. E-mail: bnogueda@yahoo.com

Received 26 August 2002

Accepted 9 July 2003
}

and looked for morphological differences that could allow for sexing on 1 st to 5 th instar nymphs.

\section{MATERIALS AND METHODS}

T. pallidipennis collected from El Progreso, in Jiutepec, Morelos, México were the original source of a laboratory colony, 120 uninfected nymphs were used. They were individually placed in a glass vial $95 \times 15 \mathrm{~mm}$, each containing a piece of folded cardboard, they were numbered and kept under controlled temperature and humidity $\left(28 \pm 2{ }^{\circ} \mathrm{C}\right.$ and $\left.60 \pm 2 \% \mathrm{RH}\right)$. The bugs were fed weekly on rabbit. Exuviae from each specimen was kept in a glass vial for chemical treatment and microscopic studies. Sex was later confirmed as they got to adult stage.

Treatment of biological material - The exuviae were placed in hot water $\left(80 \pm 2^{\circ} \mathrm{C}\right)$ for $10 \mathrm{~min}$, the genital plates were separated discarding the remaining tissues, and we conducted the following procedures: (a) $\mathrm{KOH}(10 \%)$ during $10 \mathrm{~min}$; (b) washing with distilled water for $15 \mathrm{~min}$; (c) neutralization with water-acetic acid for $10 \mathrm{~min}$; (d) dehydration with 70\% ethanol for $15 \mathrm{~min}$; (e) dehydration with $90 \%$ ethanol for $15 \mathrm{~min}$. Finally glass slide mounting with synthetic resin $(60 \%$ in toluene, Sigma 7986, lot 43 248), drying at $37^{\circ} \mathrm{C}$ for 20 days.

Microscopic analyses - We compared genital urosternites between sexes considering: form and size, separation, vestiture, color pattern, and the presence of cuticular structures like lobules, foldings, holes, etc., in or around the genital plate area. Measurement of urosternites were done with an ocular micrometer; microphotographs of the genital plates were taken with a microscope Nikon Labophot 2, equipped with a camera Nikon FX-35Dx.

Statistical analyses - Data for 9th sternite width and length were transformed by $x^{\prime}=\log (x+1)$ to remove heterocedasticity (Zar 1999), then analyzed by one-way analysis of variance and the Ryan-Einot-Gabriel-Welsch multiple range test or "REGWQ" test (Schlotzhauer \& Littell 1987). In all cases $\alpha=0.05$. We employed SAS computer software (SAS Institute 1990). 


\section{RESULTS}

From the initial 120 nymphs, 58 females and 53 males developed into adults, this is $92.5 \%$ survival under laboratory conditions.

Microscopic analysis of genital plates did not show clear differences in several morphological characters observed. We found differences in both width and length of the 9th sternite; in general it appears bigger in males (Table). Also there is morphological difference as a result of more marked lateral projections of the 9th sternite in females. Figs 1-5 show comparative microphotographs and simplified schemes of the genital plates in both sexes for 1 st to 5 th instars. Comparative development of the 9 th sternite per instar, on both males and females is shown in Fig. 6.

\section{DISCUSSION}

A good nymphal survival of $92 \%$ was observed during the study (111 adults from 120 nymphs), better than $66.7 \%$ observed by Martínez and Katthain-Duchateau (1999) when fed on hens every three days, and better than $84.6 \%$ by Mena-Segura et al. (1994) fed every 10-12 days.

Microscopic analysis of the genital plates indicates differences between sexes both in form and size of the 9 th urosternite. In general, for females it appears as a biconvex disc, narrow in the middle with curved pointed ends; in the case of males it is a wider plate curved towards the 10th sternite and pointless ends. We also observed that the 7 th and 8 th sternites have a rectangular shape in females, and a trapezoidal shape in males, short side pointing cefalad. During nymphal development the 9th sternite of the genital plates differentiates between sexes (Fig. 1), average growth of the 9th sternite increases gradually up to 4 times in width and 6.8 times in length, in male nymphs from 1 st instar until 5 th instar; for females it grows 4 times in width and 2.9 times in length (4th instar), as it changes to 5 th instar length is reduced 2.1 times its size for 1 st instar nymphs.
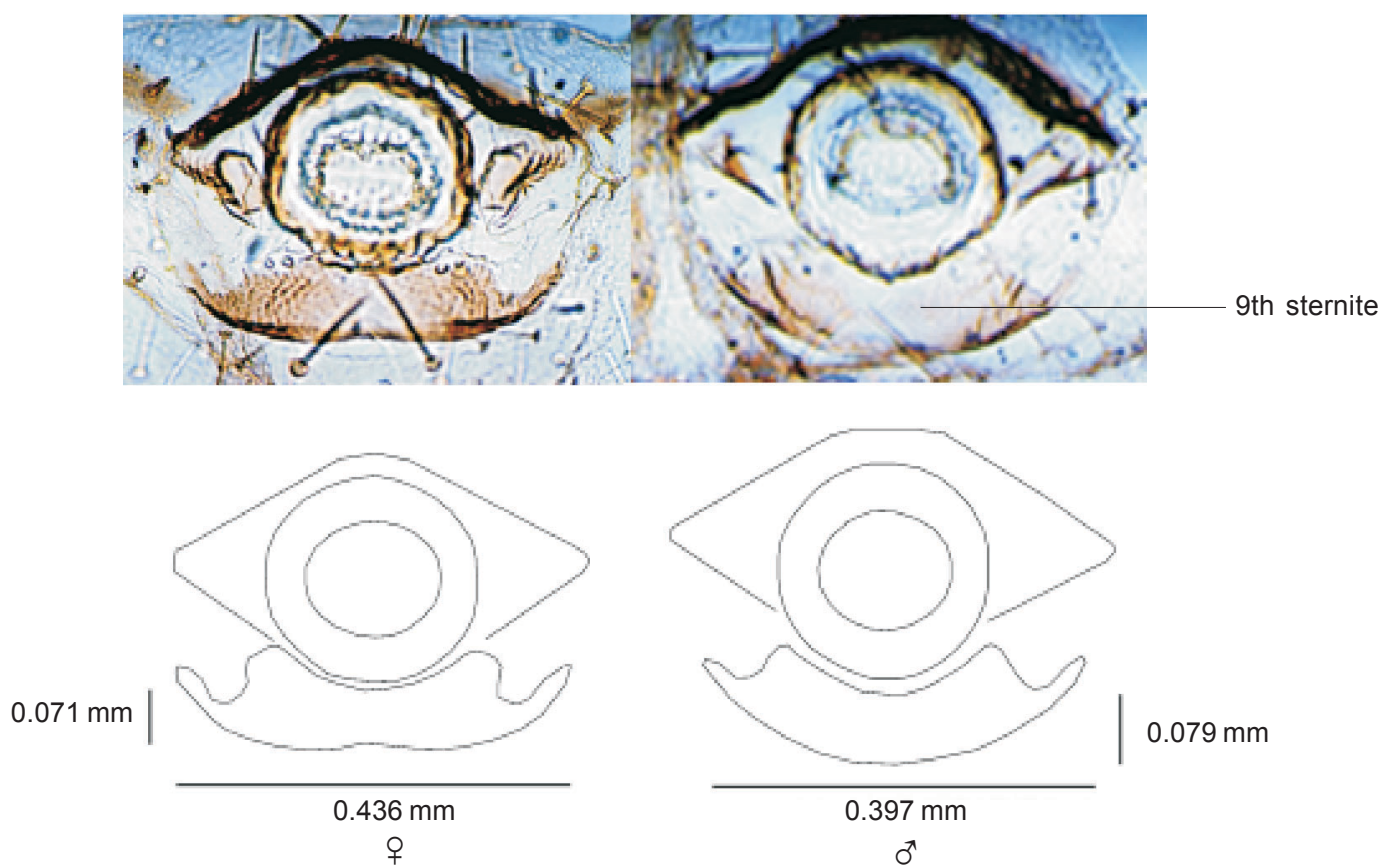

Fig. 1: Triatoma pallidipennis Stål 1872, genital plates of 1 st instar nymphs

TABLE

Genital plates of Triatoma pallidipennis Stål 1872, nymphs, recorded sizes of the 9th sternite

\begin{tabular}{|c|c|c|c|c|c|c|c|c|c|c|c|}
\hline & & \multicolumn{2}{|c|}{ N1 } & \multicolumn{2}{|c|}{ N2 } & \multicolumn{2}{|c|}{ N3 } & \multicolumn{2}{|c|}{ N4 } & \multicolumn{2}{|c|}{ N5 } \\
\hline & & 우 & $0^{\pi}$ & 우 & $0^{\pi}$ & 우 & $0^{\pi}$ & 우 & $0^{\pi}$ & 우 & $0^{*}$ \\
\hline \multirow[t]{3}{*}{ Width (mm) } & $\min$. & 0.309 & 0.379 & 0.468 & 0.476 & 0.563 & 0.619 & 0.712 & 0.855 & 1.448 & 1.401 \\
\hline & máx. & 0.436 & 0.420 & 0.547 & 0.587 & 0.722 & 0.746 & 0.950 & 0.997 & 1.686 & 1.710 \\
\hline & mean & 0.399 & 0.392 & 0.495 & 0.528 & 0.621 & 0.674 & 0.855 & 0.939 & 1.596 & 1.583 \\
\hline \multirow[t]{3}{*}{ Length (mm) } & $\min$. & 0.055 & 0.071 & 0.071 & 0.095 & 0.126 & 0.150 & 0.190 & 0.237 & 0.087 & 0.451 \\
\hline & máx. & 0.087 & 0.103 & 0.119 & 0.134 & 0.182 & 0.190 & 0.261 & 0.308 & 0.213 & 0.641 \\
\hline & mean & 0.075 & 0.082 & 0.089 & 0.106 & 0.144 & 0.165 & 0.220 & 0.277 & 0.160 & 0.563 \\
\hline
\end{tabular}

N1: 1st instar nymphs; N2: 2nd instar nymphs; N3: 3dr instar nymphs; N4: 4th instar nymphs; N5: 5th instar nymphs 

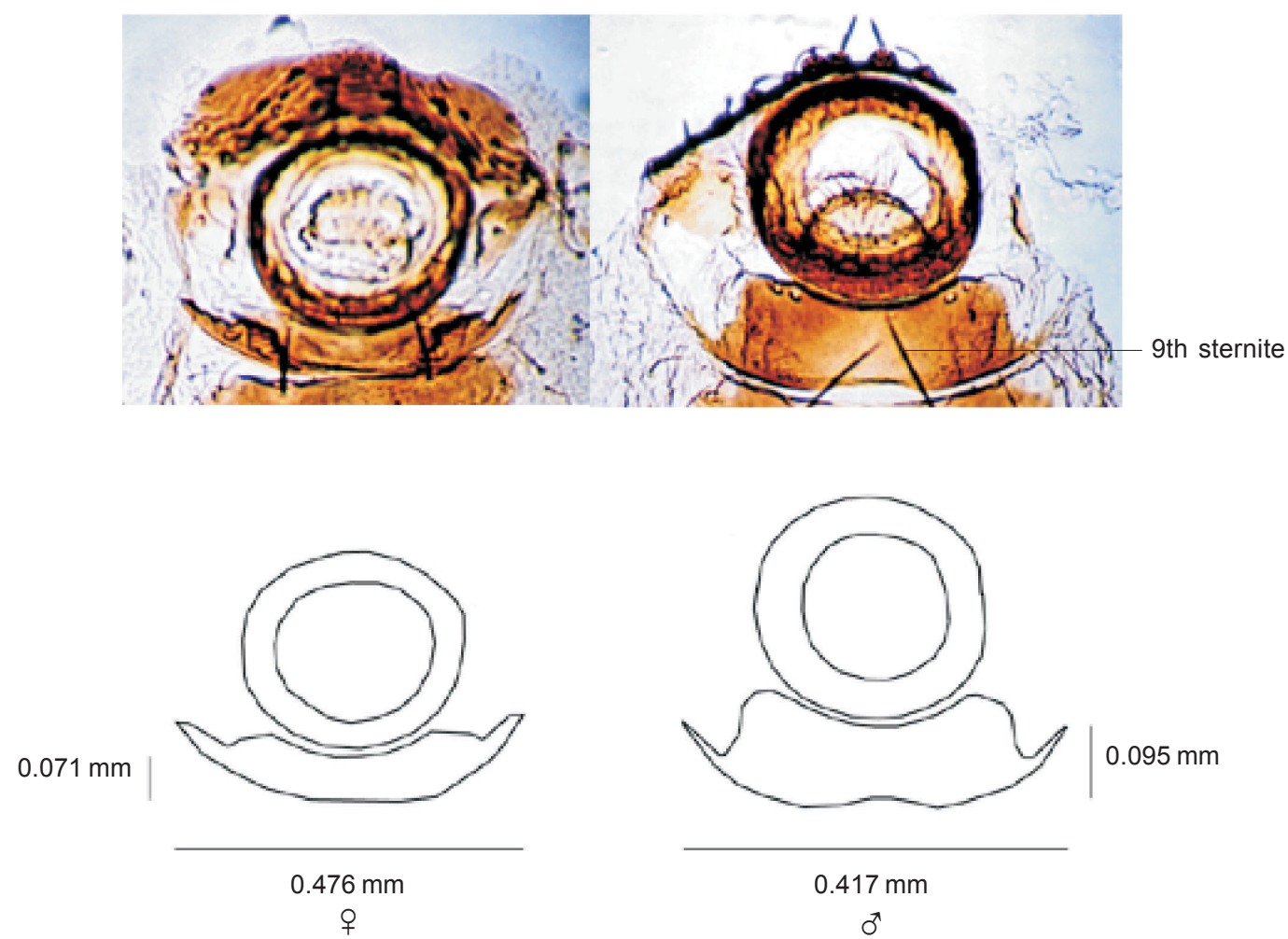

Fig. 2: Triatoma pallidipennis Stål 1872, genital plates of 2nd instar nymphs
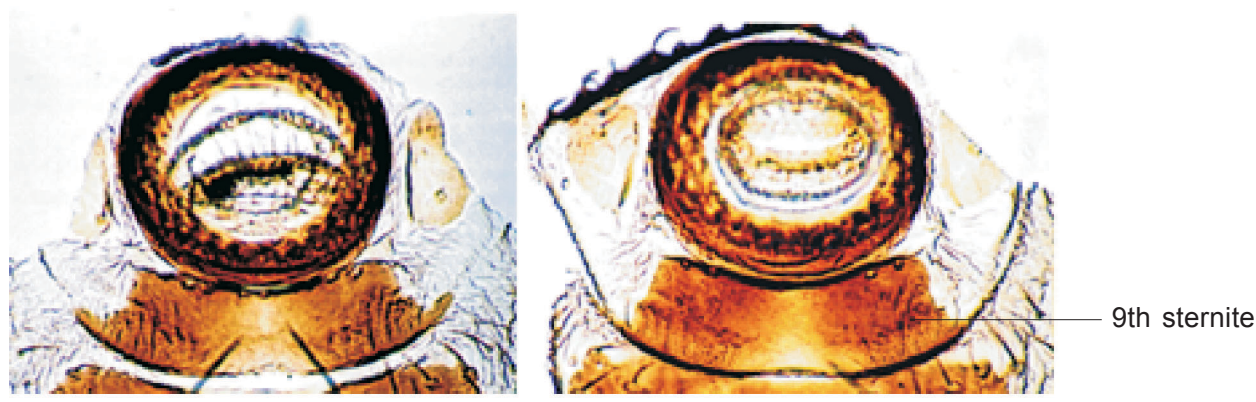

$0.143 \mathrm{~mm}$
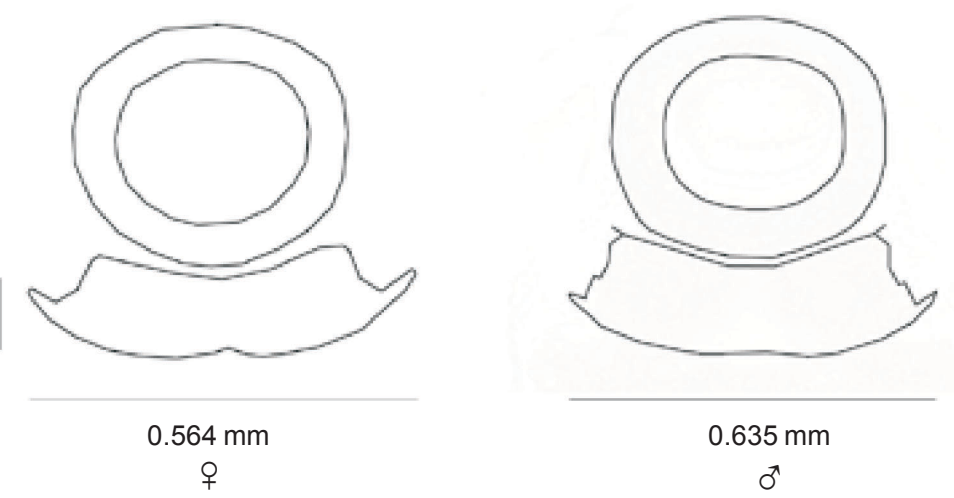

$0.167 \mathrm{~mm}$

Fig. 3: Triatoma pallidipennis Stål 1872, genital plates of 3rd instar nymphs 

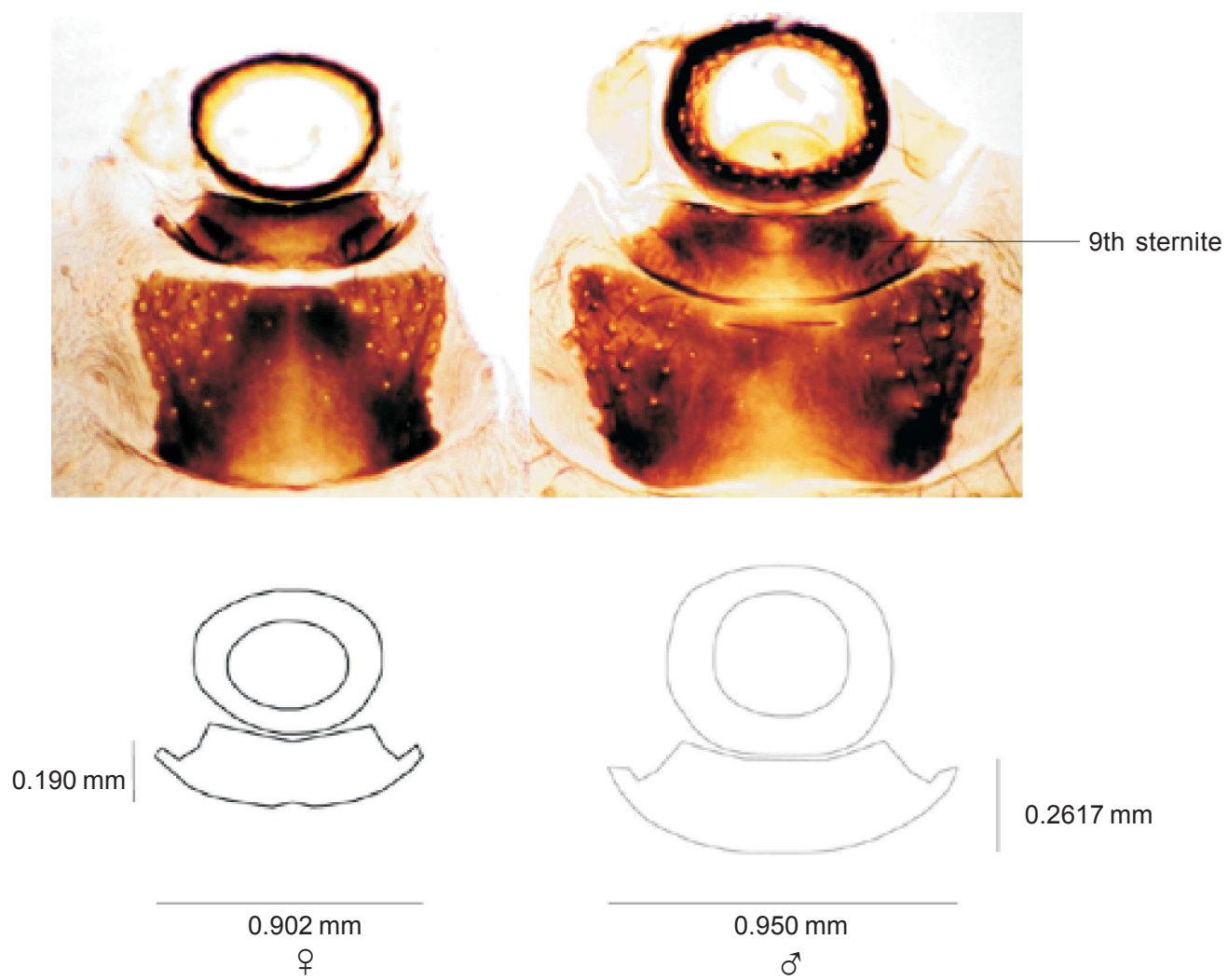

Fig. 4: Triatoma pallidipennis Stål 1872, genital plates of 4th instar nymphs
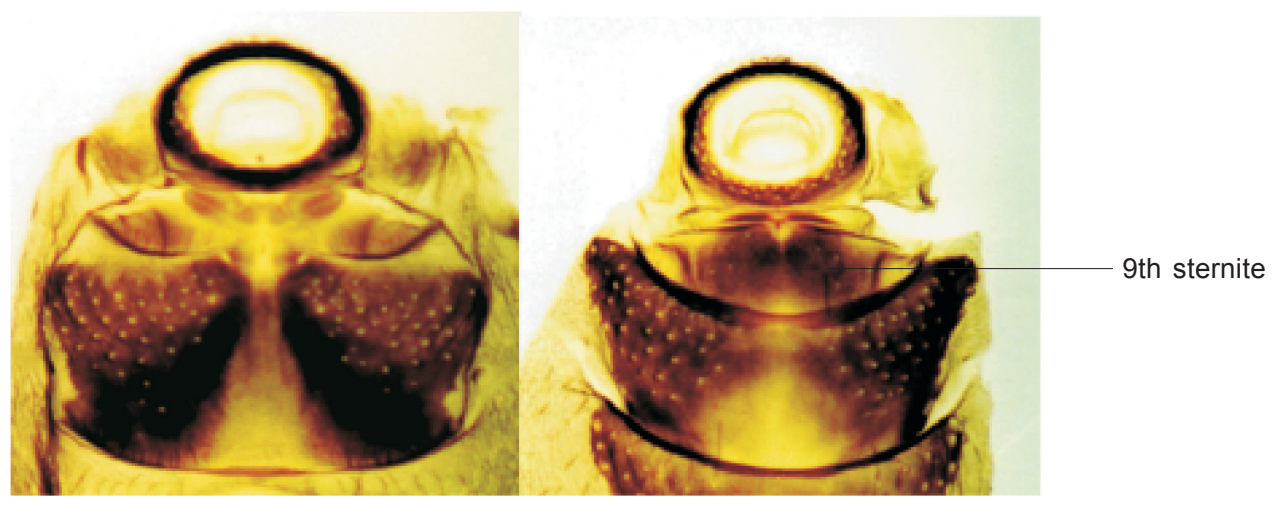

$0.166 \mathrm{~mm}$
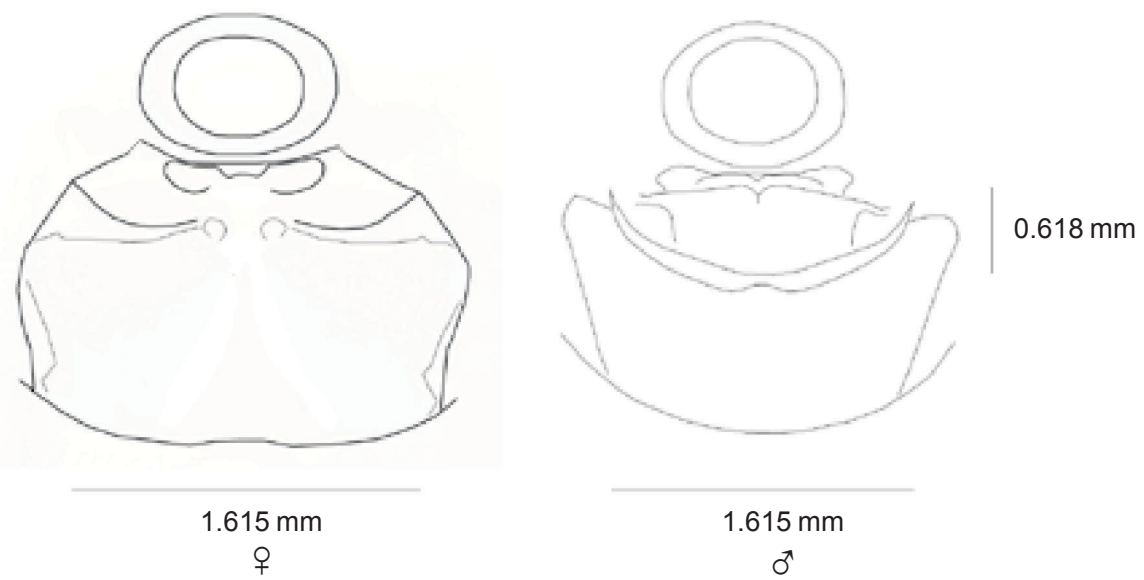

Fig. 5: Triatoma pallidipennis Stål 1872, genital plates of 5th instar nymphs 


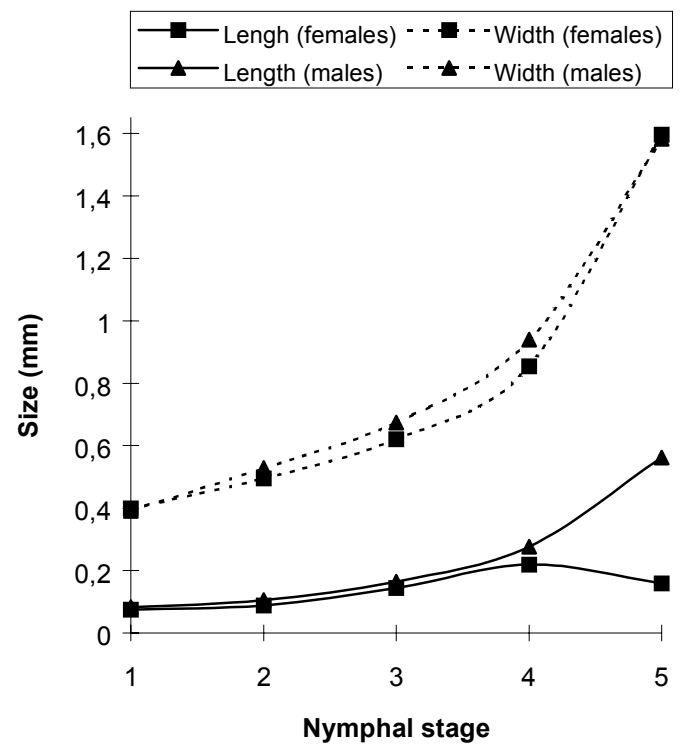

Fig. 6: Triatoma pallidipennis Stål 1872, nymphs, males and females, development of the 9 th sternite in the genital plate

On the other hand it is observed that the 9th sternite had an average increase in males of 1.4 times its width and 1.6 times its length. Females increased 1.4 times both width and length, this is considering only 1 st to 4 th instars. Males have longer 9th sternite than females: it is 1.09 times longer in 1st instar, 1.19 in 2 nd instar, 1.14 times in 3 rd instar, 1.25 in 4 th instar and 3.51 times in 5th instar nymphs.

Statistical analyses (ANOVA and REGWQ test) determined statistically significant differences between sexes in width of the 9th sternite for 2 nd, 3rd and 4th instars (Fig. 7). We found significant differences between sexes for length of the 9th sternite in every instar (Fig. 8).

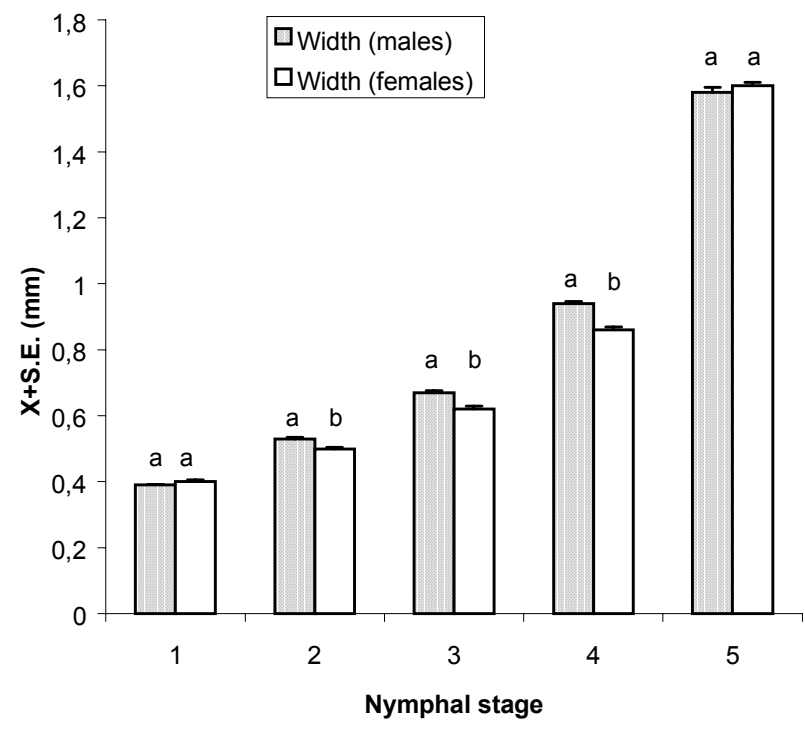

Fig. 7: Triatoma pallidipennis Stål 1872, nymphs, comparison between males and females for width of the 9 th sternite in the genital plate

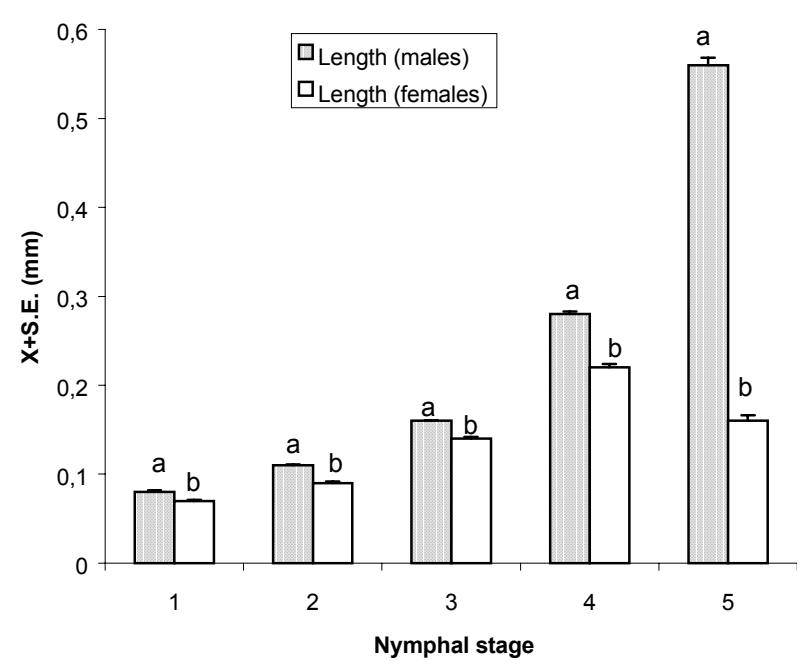

Fig. 8: Triatoma pallidipennis Stål 1872, nymphs, comparison between males and females for length of the 9th sternite in the genital plate

Our results agree with other morphometric studies conducted in South American Triatoma species (Perlowagora-Szumlewicz \& Cruz 1972, Jurberg et al. 1986, Da Rosa et al. 1992). We consider that it is possible to sex $T$. pallidipennis nymphs considering the size and shape of the 9th urosternite.

\section{REFERENCES}

Beltrán L, Carcavallo RU 1985. México. In RU Carcavallo, E Rabinovich, J Tonn (eds), Factores Biológicos y Ecológicos en la Enfermedad de Chagas, Ministerio de Salud y Acción Social, República Argentina, p. 437-442.

Corrêa FMA, Carvalheiro JR, Barreto MP 1964. Estudos sôbre reservatórios e vetores silvestres do Trypanosoma cruzi. V: Observações sôbre a ecologia e a morfologia do Psammolestes coreodes Bergroth, 1911 (Hemiptera, Reduviidae). Rev Brasil Biol 24: 259-268.

Corrêa RR 1954. Estudos sobre a morfología externa do gênero Triatoma Laporte, 1833 (Hemiptera, Reduviidae). Folia Clin Biol 22: 23-50.

Da Rosa JA, Soares Barata JM, Barelli N, Ferreira Santos JL, Belda Nieto FM 1992. Sexual distinction between 5th instar nymphs of six species of Triatominae (Hemiptera, Reduviidae). Mem Inst Oswaldo Cruz 87: 257-264.

Espínola HN 1966. Nota sobre diferenças sexuais em formas imaturas de Triatominae (Hemiptera, Reduviidae). Rev Bras Biol 26: 263-267.

Galindez Giron I, Rocha DS, Lent H, Carcavallo RU, Jurberg J, Galvão C, Barbosa HS, Martínez A, Barata JM, Da Rosa JA 1999. Estadios ninfais. In RU Carcavallo, I Galindez Giron, J Jurberg, H Lent (eds), Atlas dos Vetores da Doença de Chagas nas Americas, Fiocruz, Rio de Janeiro, Vol II, p. 449-513.

Galliard H 1935. Recherches sur les réduvidés hématophages Rhodnius et Triatoma. Ann Parasitol Hum Comp 13: 289306.

Gonçalvez TCM, Jurberg J, Costa JM, De Souza W 1985. Estudo morfológico comparativo de ovos e ninfas de Triatoma maculata (Erichson, 1848) e Triatoma pseudomaculata Correa \& Espínola, 1964 (Hemiptera, Reduviidae, Triatominae). Mem Inst Oswaldo Cruz 80: 263-276. 
Jurberg J, Gonçalvez TCM, Costa JM, De Souza W 1986. Contribuição ao estudo morfológico de ovos e ninfas de Triatoma brasiliensis Neiva, 1911 (Hemiptera, Reduviidae, Triatominae). Mem Inst Oswaldo Cruz 81: 111-120.

Jurberg J, Guedes Lima M, Rocha DS, Carcavallo RU, Galvão C 1998. Descrição dos ovos e ninfas de Triatoma melanosoma Martínez, Olmedo \& Carcavallo, 1987 (Hemiptera, Reduviidae). Entomol Vect 5: 67-84.

Lent H, Jurberg J 1969. Observações sobre o ciclo evolutivo, em laboratório, de Pastrongylus geniculatus (Latreille, 1811) (Hemiptera, Reduviidae, Triatominae). An Acad Bras Cienc 41: 125-131.

Lent H, Wygodzinsky P 1979. Revision of the Triatominae (Hemiptera: Reduviidae) and their significance as vectors of Chagas disease. Bull Am Mus Nat Hist 163: 131-176.

Martín E, Dávila O 1981. Diferencias sexuales en ninfas de Triatoma phyllosoma (Hemiptera, Reduviidae). Folia Entomol Mex 48: 68.

Martínez Ibarra JA, Katthain-Duchateau G 1999. Biology of Triatoma pallidipennis Stål 1945 (Hemiptera: Reduviidae: Triatominae) under laboratory conditions. Mem Inst Oswaldo Cruz 94: 837-839.

Mena-Segura C, Carcavallo RU, Galíndez-Girón I, Canale D 1994. Ciclo de vida de Triatoma pallidipennis (Stål 1872) (I) (Hemiptera: Reduviidae: Triatominae). Entomol Vect 1: 33-38.
Perlowagora-Szumlewicz A, Nigri da Cruz H 1972. Triatominae (Hemiptera, Reduviidae): sex identification in immature forms of vectors of Chagas' disease. Rev Inst Med Trop São Paulo 14: 6-11.

Ramírez Pérez J 1969. Estudio sobre la anatomía de Rhodnius prolixus. Rev Venez Sanid Assist Soc 34: 10-98.

Ryckman RE 1962. Biosystematics and hosts of Triatoma protracta complex in North America (Hemiptera: Reduviidae) (Rodentia: Cricetidae). Univ California Publ Entomol 27: 93-240.

Salgado AA, Godoy TL, Rocha LSC, Cerqueira E, Calabria PV 1979. Encontro casual, capturas e acasalamentos de mutante de olhos vermelhos de Panstrongylus megistus (Burmeister, 1853). Cien Cult 31: 68-671.

SAS Institute 1990. SAS system for personal computers, release 6.04. SAS Institute Inc. Cary, North Carolina, US.

Schlotzauer SD, Littell RC 1987. SAS system for elementary statistical analysis. SAS Institute Inc. Cary, North Carolina, US.

Velasco-Castrejón O 1991. La Enfermedad de Chagas, Publicación Técnica del Instituto de Diagnóstico y Referencia Epidemiológica, México, DF, 56 pp.

Zar JH 1999. Biostatistical Analysis, 4th ed, Prentice-Hall Inc., New Jersey, US, 663 pp.

Zárate LG, Zárate RJ 1985. A checklist of the triatominae (Hemiptera: Reduviidae) of Mexico. Intern J Entomol 27: 102-127. 